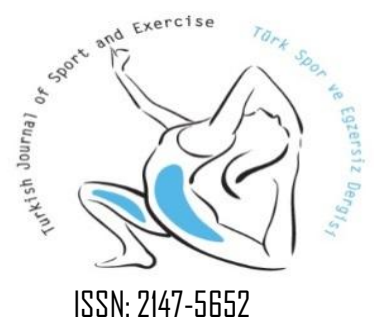

\title{
Comparison of Agility, Vertical Jump and Speed Parameters in Children Between 6-12 Years
}

\author{
Yeliz DOĞRU1
}

1-İzmir Katip Çelebi University, Department of Sports, Izmir, Turkey.

Correspondence: Yeliz Doğru, İzmir Katip Çelebi University, Balatçık Street, 35620 Çiğli, Izmir, Turkey. Tel: +902323293535 (1435), Fax: +90 232

3860888, E-mail: yeliz.dogru@hotmail.com

\begin{abstract}
The aim of the study is to compare the agility, vertical jump and velocity parameters in children between 6-12 years of age. One hundred thirty-six children (61 girls, 74 boys) participated as volunteers. The t-test was applied to the participants as a measure of agility test. Vertical jump and 20 meters speed test were applied. Statistics were performed using by SPSS package program. The data were evaluated by the Shapiro-Wilk test for normal distribution. Mann Whitney U test was used for intergroup comparisons. Accordingly, there is a significant difference in favor of males in the vertical jump in the 10-year age group $(p<0.05)$. There is a significant difference between males and females in the 9 and 10 age groups in favor of males in vertical jump and speed $(\mathrm{p}<0.05)$.There was no statistically significant difference in the agility test, but the data showed that men performed better.
\end{abstract}

Key Words:Agility, vertical jump, speed

\section{INTRODUCTION}

Sportive abilities are characterized by different psychomotor characteristics. These; force, speed, endurance, skill and range of motion. Sportive abilities are characterized by different psychomotor characteristics. These are; force, speed, endurance, skill, and range of motion. These characteristics are the factors that determine how successful a person will be more successful and in which sport. Durability feature may be a prominent athlete marathon runner, who has a very good speed can be a sprinter, someone who uses his feet well can be a footballer, who use a good hand can be more successful in using volleyball (1). The width of movement in sports is an expression of flexibility. There are four main features of muscle tissue, namely: extensibility, flexibility, excitability, and contraction. The extensibility and flexibility of these forms the width of motion $(2,3)$. Elongation is the ability of the muscle to stretch. Flexibility; the ability to return to the normal length of the muscle after stretching or after contraction (4).Children between the ages of 6 and 12, rather than gaining new skills, demonstrate the basic skills they have previously gained more fluently and accurately. This phase of motor development is the stage of development of basic movements. Here, the term sports has been widely used; that is, it is adopted not only as a competition but also as a means of activities such as recreation, play, dance $(5,6)$. It is the transition phase of the age of seven to eight. During this period, performance is highlighted and efforts are made to increase. Performance is expected to increase with strength, durability, reaction time, movement time and balance (7). After this period, special movement skills are introduced and this phase includes children aged 11-13. At this stage, Starts to choosing a branch. Children are willing to learn and practice their mobility skills. The branch of movement which is specific to the sports branch is also called the branching period (8). In the age of 6-12 years, the child's perceptual 
abilities are sharpened. Sensory-motor organs work more and more harmoniously. Thus, at the end of this semester, the child can achieve numerous complex skills. For example, hitting the flung baseball; age, application, visual acuity, running ability, reaction and movement time and sensorymotor integration depending on. It is imperative for the children to experiment for the maximum maturation of his movement skills. In other words, children can develop motor skills by developing their perceptual processes during normal maturation process (9).

Motor development; it is a process that continues throughout the acquisition of a child's movement patterns and skills. Continuous changes and developments are involving the interaction of many functions. These functions include neuromuscular maturation, an important genetic component. This maturation is realized through the environment and social life of a social being (10). Speed can be defined as the speed at which the whole body or body parts occur when applying a movement. Briefly, it can be defined as the ability to move the body or a part at high speed (11).

Based on this information, it was aimed to compare the agility, vertical jump and velocity parameters in children aged 6-12 years. Thus, we will have an idea about age groups by revealing the difference between the parameters we examined and comparing them in terms of gender.

\section{MATERIALS \& METHODS}

One hundred thirty-six children (61 girls, 74 boys) aged 6-12 years in basketball, volleyball and football branches participated in the study voluntarily. Participants who were invited by faceto-face interview with their families were informed about the purpose and content of the study. The volunteer consent form was signed before the study. Body composition, body weight, body mass index $(\mathrm{BMI})$, fat ratio $(\mathrm{kg})$ and fat ratio (\%) were performed by body composition analysis (Tanita BC 418, USA) based on bioelectric impedance method. The 4 funnel tracks are arranged in the T-shape for T-test section. Then run to the left ( $\mathrm{C}$ funnel) side step and touch the $C$ funnel with the left hand. Then the right hand ( $\mathrm{D}$ funnel) runs sideways and touches it with the right hand. Then come to $B$ with side running and then the funnel and touch it with the left hand. It then returns to A funnel by running back. The chronometer is stopped as soon as you reach the A funnel (Figure 1). The best duration of the participant will be recorded (12).

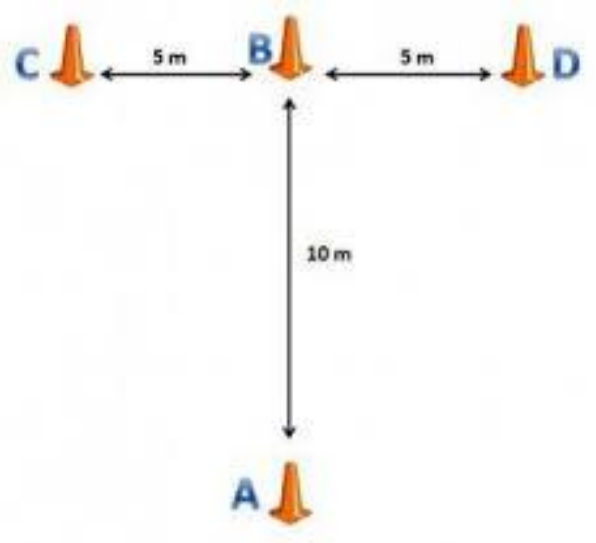

Figure 1. T-test

The vertical jump test was performed using the Jump Meter. Athletes, time and distance scale on the sensitive ground without taking the step and the top of the strength has jumped upwards. The distance he jumped was determined in inches on the device. Athletes jumped two times. The best degree is recorded as the vertical jump values.

\section{Statistical Analysis}

Statistical analysis was performed by in SPSS 23.00 package program. The data were evaluated by the Shapiro-Wilk test for normal distribution. All data were expressed as mean and standard deviation. The Mann Whitney U test was used to compare genders. Significance was accepted at $p$ $<0.05$. 


\section{RESULTS}

Descriptive parameters of age groups are shown in Tables 1, 2, 3, 4 and 5.

Table 1. Descriptive parameters of age group 6

\begin{tabular}{|c|c|c|c|c|c|}
\hline \multirow{2}{*}{ Age } & \multirow{2}{*}{ Parameters } & \multicolumn{2}{|c|}{ Girls (n=19) } & \multicolumn{2}{|c|}{ Boys $(n=23)$} \\
\hline & & Min-max & Mean \pm SD & Min-max & Mean \pm SD \\
\hline \multirow{8}{*}{6 years } & Height $(\mathrm{cm})$ & $94-128$ & $116.05 \pm 8.83$ & $103-139$ & $119.78 \pm 8.4$ \\
\hline & Body weight (kg) & $13.2-32$ & $19.94 \pm 4.23$ & $33.7-22.73$ & $22.73 \pm 5.17$ \\
\hline & Body fat $(\%)$ & $13.1-31.6$ & $18.67 \pm 5.28$ & $3-33.4$ & $18.17 \pm 5.79$ \\
\hline & Body fat (kg) & $2.10-10.10$ & $3.82 \pm 1.85$ & $1-10.7$ & $4.32 \pm 2.18$ \\
\hline & BMI $\left(\mathrm{kg} / \mathrm{cm}^{2}\right)$ & $12.1-20.8$ & $14.69 \pm 1.88$ & $13.2-20.5$ & $15.66 \pm 1.96$ \\
\hline & Vertical jump $(\mathrm{cm})$ & $10-28$ & $16.1 \pm 4.79$ & $9-27$ & $18.6 \pm 4.66$ \\
\hline & 20 m. speed (sec) & $4.45-6.44$ & $5.27 \pm 0.59$ & $4.18-6.32$ & $5.04 \pm 0.49$ \\
\hline & $\mathrm{T}$ test $(\mathrm{sec})$ & $9.25-14.12$ & $11.46 \pm 2.64$ & $8.74-13.54$ & $10.1 \pm 4.65$ \\
\hline
\end{tabular}

Table 2. Descriptive parameters of age group 7

\begin{tabular}{|c|c|c|c|c|c|}
\hline \multirow{2}{*}{ Age } & \multirow{2}{*}{ Parameters } & \multicolumn{2}{|c|}{ Girls (n=10) } & \multicolumn{2}{|c|}{ Boys $(n=13)$} \\
\hline & & Min-max & Mean \pm SD & Min-max & Mean \pm SD \\
\hline \multirow{8}{*}{7 years } & Height $(\mathrm{cm})$ & $119-142$ & $125.1 \pm 7.74$ & $122-131$ & $126.23 \pm 3.0$ \\
\hline & Body weight $(\mathrm{kg})$ & $17.9-45.6$ & $25.96 \pm 7.73$ & $20.7-42.7$ & $26.58 \pm 5.49$ \\
\hline & Body fat $(\%)$ & 3-34.1 & $18.77 \pm 8.87$ & $12.9-38.9$ & $20.11 \pm 6.7$ \\
\hline & Body fat (kg) & $1.7-15.5$ & $5.35 \pm 4.17$ & $2.7-16.6$ & $5.66 \pm 3.53$ \\
\hline & BMI $\left(\mathrm{kg} / \mathrm{cm}^{2}\right)$ & $12.6-22.6$ & $16.3 \pm 2.91$ & $13.9-26.1$ & $16.66 \pm 3.16$ \\
\hline & Vertical jump $(\mathrm{cm})$ & $11-25$ & $17.14 \pm 3.25$ & $10-24$ & $19.84 \pm 4.12$ \\
\hline & $20 \mathrm{~m}$. speed $(\mathrm{sec})$ & $4.23-5.80$ & $5.01 \pm 0.52$ & $4.15-5.98$ & $4.82 \pm 0.55$ \\
\hline & T test (sec) & $9.88-13.48$ & $10.67 \pm 15.2$ & $8.56-13.56$ & $9.67 \pm 15.1$ \\
\hline
\end{tabular}

Table 3. Descriptive parameters of 8 age group

\begin{tabular}{lllccc}
\hline \multirow{2}{*}{ Age } & \multicolumn{1}{c}{ Parameters } & \multicolumn{2}{c}{ Girls $(\mathbf{n}=\mathbf{1 0})$} & \multicolumn{2}{c}{ Boys $(\mathbf{n}=\mathbf{1 6})$} \\
\cline { 2 - 5 } & & Min-max & Mean \pm SD & Min-max & Mean \pm SD \\
\hline \multirow{5}{*}{ 8yeight $(\mathrm{cm})$} & $123-138$ & $131.4 \pm 4.88$ & $108-145$ & $129.5 \pm 9.12$ \\
\cline { 2 - 6 } & Body weight $(\mathrm{kg})$ & $19.1-33.7$ & $25.98 \pm 4.89$ & $13.9-46.6$ & $27.83 \pm 9.32$ \\
\cline { 2 - 6 } & Body fat $(\%)$ & $9-28$ & $16.43 \pm 6.23$ & $9-30.9$ & $17.16 \pm 6.64$ \\
\cline { 2 - 6 } & Body fat $(\mathrm{kg})$ & $1.7-9$ & $4.5 \pm 2.44$ & $1.3-13.7$ & $5.31 \pm 3.91$ \\
\cline { 2 - 6 } & BMI $\left(\mathrm{kg} / \mathrm{cm}^{2}\right)$ & $11.5-18.9$ & $14.98 \pm 2.35$ & $11.9-22.3$ & $16.15 \pm 3.32$ \\
\cline { 2 - 6 } & Vertical jump $(\mathrm{cm})$ & $11-23$ & $19.1 \pm 2.4$ & $13-25$ & $20.15 \pm 6.1$ \\
\cline { 2 - 6 } & 20 m. speed $(\mathrm{sec})$ & $4.18-6.39$ & $4.95 \pm 0.76$ & $4.31-5.21$ & $4.74 \pm 0.26$ \\
\cline { 2 - 6 } & T test $(\mathrm{sec})$ & $9.75-13.45$ & $10.56 \pm 4.12$ & $8.42-13.32$ & $9.56 \pm 3.48$ \\
\hline
\end{tabular}

Table 4. Descriptive parameters of 9 age group

\begin{tabular}{|c|c|c|c|c|c|}
\hline \multirow{2}{*}{ Age } & \multirow{2}{*}{ Parameters } & \multicolumn{2}{|c|}{ Girls $(\mathrm{n}=11)$} & \multicolumn{2}{|c|}{ Boys $(\mathrm{n}=12)$} \\
\hline & & Min-max & Mean \pm SD & Min-max & Mean \pm SD \\
\hline \multirow{8}{*}{9 years } & Height $(\mathrm{cm})$ & $132-153$ & $139.18 \pm 5.94$ & $119-150$ & $139.75 \pm 8.4$ \\
\hline & Body weight (kg) & $21.2-40.5$ & $29.03 \pm 5.54$ & $25.9-50.7$ & $36.55 \pm 8.18$ \\
\hline & Body fat $(\%)$ & $3-28.7$ & $14.88 \pm 8.02$ & $12.4-30.6$ & $21.06 \pm 5.53$ \\
\hline & Body fat $(\mathrm{kg})$ & $1-11.6$ & $4.59 \pm 3.27$ & $3.6-14.7$ & $8.02 \pm 3.74$ \\
\hline & BMI $\left(\mathrm{kg} / \mathrm{cm}^{2}\right)$ & $12.2-34$ & $25.76 \pm 35.97$ & $14.9-22.5$ & $18.51 \pm 2.46$ \\
\hline & Vertical jump (cm) & $15-28$ & $20.21 \pm 6.12$ & $20-27$ & $24.1 \pm 3.25$ \\
\hline & 20 m. speed (sec) & $3.98-5.57$ & $4.69 \pm 0.46$ & $2.39-5.23$ & $3.87 \pm 1.22$ \\
\hline & T test $(\mathrm{sec})$ & $9.65-13.2$ & $10.21 \pm 15.4$ & $8.32-13.1$ & $9.12 \pm 15.46$ \\
\hline
\end{tabular}




\begin{tabular}{|c|c|c|c|c|c|}
\hline \multirow{2}{*}{ Age } & \multirow{2}{*}{ Parameters } & \multicolumn{2}{|c|}{ Girls (n=11) } & \multicolumn{2}{|c|}{ Boys $(n=10)$} \\
\hline & & Min-max & Mean \pm SD & Min-max & Mean \pm SD \\
\hline \multirow{8}{*}{ 10years } & Height $(\mathrm{cm})$ & $133-157$ & $145 \pm 12$ & $138-159$ & $146.7 \pm 7.36$ \\
\hline & Body weight $(\mathrm{kg})$ & $27.7-61.3$ & $40.7 \pm 18.04$ & $23.1-63.4$ & $43.09 \pm 11.85$ \\
\hline & Body fat $(\%)$ & $15.5-35.6$ & $23.4 \pm 10.71$ & $6.3-35.9$ & $20.42 \pm 8.41$ \\
\hline & Body fat (kg) & $4.3-21.8$ & $10.8 \pm 9.57$ & $1.5-20.1$ & $9.49 \pm 5.49$ \\
\hline & BMI $\left(\mathrm{kg} / \mathrm{cm}^{2}\right)$ & $15.7-24.9$ & $18.76 \pm 5.31$ & $12.1-26.3$ & $19.79 \pm 4.27$ \\
\hline & Vertical jump (cm) & $20-29$ & $25.65 \pm 5.17$ & $22-34$ & $28.1 \pm 2.54$ \\
\hline & 20 m. speed (sec) & $4.40-4.72$ & $4.6 \pm 0.17$ & $3.67-4.56$ & $3.88 \pm 0.42$ \\
\hline & $\mathrm{T}$ test $(\mathrm{sec})$ & $9.56-12.84$ & $9.76 \pm 45.1$ & $8.12-12.58$ & $9.10 \pm 1.65$ \\
\hline
\end{tabular}

The gender comparison of the parameters is shown in Table 6. According to this, there is a significant difference between boys and girls in 9 and 10 age groups in favor of males in vertical jump and speed.

\begin{tabular}{lccccc}
\hline \multicolumn{1}{l}{ Table 6. Comparison of vertical jump, agility and speed data in terms of gender } & & \\
\hline & 6 years & 7 years & 8 years & 9 years & 10 years \\
& $\mathrm{p}$ & $\mathrm{p}$ & $\mathrm{P}$ & $\mathrm{p}$ & .354 \\
\hline Vertical jump $(\mathrm{cm})$ & .110 & .165 & .265 & $.039^{*}$ & $.046^{*}$ \\
\hline 20m Speed $(\mathrm{sec})$ & .215 & .687 & .493 & .154 & $.042^{*}$ \\
\hline T test $(\mathrm{sec})$ & .154 & .215 & .226 & & .354 \\
\hline${ }^{*} \mathrm{p}<0.05$ & & & & \\
\hline
\end{tabular}

\section{DISCUSSION \& CONCLUSION}

One hundred thirty-six children (61 girls, 74 boys) participated as volunteers between the ages of 6-12. The age group consisted of 42 participants (19 female, 23 male). Twenty-three participants from 7 age group (10 girls, 13 boys). Twenty-six participants (10 girls, 16 boys) aged 8 years. Twentythree participants (11 girls, 12 boys) aged 9 years. The age group ten consisted of 22 participants (11 females, 10 males). All participants' vertical jump, $20 \mathrm{~m}$ speed, and agility tests were compared. According to this, there is a significant difference between boys and girls in nine and ten age groups in favor of males in vertical jump and speed.

Kara (2018), the aim of this study was to investigate the relationship between body mass index and speed in male and female athletes aged 10 years. as a result, it is possible to mention an improvement in speed characteristics in parallel with the positive increase in BMI, albeit at a low level. (13). It is stated in the sources that the bone length reached the endpoint in the first 2-4 years following puberty in girls (14). With age progression, the increase in height and body weight together with passive physical activity are thought to negatively affect girls' long distance performances. It is seen that the boys perform better when the children who are engaged in sports are considered to be better at the same time when their long-distance values are better.

Savucu et al. (2004) found that the average age of the basketball players, 14 from the junior category, 36 from the star category, 32 from the junior category and 30 from the basketball players, the average of the vertical jump values of small males was found to be $36.75 \pm 3.82 \mathrm{~cm}$. The male average of the stars was found to be $45.55 \pm 4.03 \mathrm{~cm}$. Young people have found an average of $50.83 \pm 5.26$ $\mathrm{cm}$ (15). Erikoglu et al (2009) evaluated the performance parameters of the Eurofit test battery according to gender and age groups in children aged 7-12 years. In conclusion, it was reported that boys and girls showed similar development up to the age of 10, however, boys from this age showed a higher rate of development in some parameters than girls (16). Anil (2001), in the study conducted by female basketball players in the 14-16 age group, found that the vertical jump values were $33.58 \mathrm{~cm}$ in the experimental group, $42.17 \mathrm{~cm}$ in the posttraining group, and $33.25 \mathrm{~cm}$ in the control group before the training and $33.08 \mathrm{~cm}$ in the post-training period (17). Williams et al (2011), $10 \mathrm{~m}$ sprint times in their study for 40 football players under age 12 $1.98 \pm 0.09$. Mean age of 13 for 47 football players was reported to be $1.97 \pm 0.34$ (18). Girard and Millet (2009) reported that 12 tennis players with ages of $13.6 \pm 1.4$ years had $5 \mathrm{~m}$ sprint and $10 \mathrm{~m}$ sprint 
performance as $1.19 \pm 0.07$ and $2.02 \pm 0.14$, respectively (19).

In our study, no difference was observed between the age groups in terms of gender in the agility test. However, it is possible to say that the boys have completed the test at a higher degree than

\section{REFERENCES}

1. Bompa TO. Total training for young champions, Human Kinetics, 2000.

2. Fox EL, Bowers RW, Foss ML. The physiological basis of physical education and athletics. William C Brown Pub, 1989

3. Haywood K, Getchell N. Life Span Motor Development 6th Edition. Human Kinetics, 2014.

4. Selvi İ. Farklı Branşlarda Bulunan Sporcularda ve Sedanterlerde Kas Kuvvetinin Esneklik ile İlişsisi, Atatürk Üniversitesi, Erzurum, 2009.

5. Diallo O, Dore E, Duche P, Van Praagh E. Effects of plyometric training followed by a reduced training programme on physical performance in prepubescent soccer players. Journal of sports medicine and physical fitness, 2001;41(3): 342.

6. Medicine ACOS. ACSM's resource manual for guidelines for exercise testing and prescription. Lippincott Williams \& Wilkins, 2012

7. Bunc V, Psotta R. Physiological profile of very young soccer players. Journal of sports medicine and physical fitness, 2001;41(3): 337.

8. Muratlı S. Çocuk ve Spor Antrenman Bilimi Yaklaşımıyla. Nobel Basımevi, 2003; 7-38.

9. Gallahue DL. Understanding motor development in children. John Wiley \& Sons, 1982

10. Malina RM, Bouchard C, Bar-Or O, Growth, Maturation, and Physical Activity. Human kinetics, 2004.

11. Bale P. Anthropometric, body composition and performance variables of young elite female basketball players. The Journal of sports medicine and physical fitness, 1991; 31(2):173-177.

12. Pauole K, Madole K, Garhammer J, Lacourse M, Rozenek R. Reliability and validity of the T-test as a measure of agility, leg power, and leg speed in college-aged men and women. The Journal of Strength \& Conditioning Research, 2000;14(4):443-450.

13. Kara İ, Spor Okullarındaki Çocukların Beden Kitle İndeksi İle Sürat İlişkisinin İncelenmesi. İstanbul Gelişim Üniversitesi Sağlık Bilimleri Enstitüsü, Yüksek Lisans Tezi, 2018.

14. Rogol AD, Roemmich JN, Clark PA, Growth at Puberty. Journal of adolescent health, 2002;31(6):192-200.

15. Savucu Y, Polat Y, Ramazanoğlu F, Karahüseyinoğlu MF, Biçer YS. Alt yapıdaki küçük, yıldız ve genç basketbolcuların bazı fiziksel uygunluk parametrelerinin incelenmesi. Firat Üniversitesi Sağlık Bilimleri Dergisi, 2004;18(4):205-209.

16. Erikoğlu G, Özkamçı H, Golmoghanı N, Suveren C, Tuğçe TOT, Şahin N, Güzel NA. 7-12 Yaş Çocuklarda Cinsiyet Ve Turk ل Sport Exe 2019; 21(2): 355-359

(4) 2019 Faculty of Sport Sciences, Selcuk University the girls. A significant difference was found in favor of males in terms of sex in the 10 years age group in vertical jump and speed. It can be said that there is a proportional change in aerobic and anaerobic performance along with age-related anthropometric properties.

Yaş Gruplarına Göre Eurofit Test Bataryası İle Performans Parametrelerinin Değerlendirilmesi. Gazi Beden Eğitimi ve Spor Bilimleri Dergisi, 2009;14(4), 49-64.

17. Anıl F, Erol E, Pulur A, Pliometrik Çalışmaların 14-16 Yaş Grubu Bayan Basketbolcuların Bazı Fiziksel ve Fizyolojik Parametreleri Üzerine Etkisi. Gazi Bed. Eğt. ve Spor Bilimleri Dergisi, 2001;6(2):19-26.

18. Williams CA, Oliver JL, Faulkner J, Seasonal monitoring of sprint and jump performance in a soccer youth academy. International journal of sports physiology and performance, 2011;6(2):264-275.

19. Girard O, Millet GP, Physical determinants of tennis performance in competitive teenage players. The Journal of Strength\& Conditioning Research, 2009;23(6):1867-1872. 